\title{
Sugar, fructose, uric acid and hypertension in children and adolescents
}

\author{
Francesca Viazzi ${ }^{*}$, Simonetta Genovesi ${ }^{2}$, Maria Amalia Ambruzzi ${ }^{3}$, Marco Giussani ${ }^{4}$ \\ From 71st Congress of the Italian Society of Pediatrics. Joint National Meeting SIP, SIMGePeD, Study Group \\ on Pediatric Ultrasound, SUP Study Group on Hypertension \\ Rome, Italy. 4-6 June 2015
}

Fructose consumption has been increasing over recent decades and is believed to play a role in the rising epidemic of metabolic disorders and hypertension (HT) in children $[1,2]$. This theory is supported by epidemiological and experimental studies in animals and humans.

High-fructose diets upregulate sodium and chloride transporters, resulting in salt overload that increases blood pressure (BP) [3]. Moreover, excess fructose has also been found to deregulate vasoconstrictors and vasodilators, and over-stimulate the sympathetic nervous system. Metabolism of fructose is mediated by fructokinase, which uses ATP as a phosphate donor. Unlike glucose, there is no feedback mechanism regulating fructokinase. As a result, AMP is continuously involved in the production of uric acid (UA) [4]. In adolescents in the US, serum UA was showed to increase from the lowest to the highest category of fructose-sweetened beverage intake and this increment was paralleled by an increase in BP, even independently of body mass index [5]. These data suggest pathways other than obesity relating soft drinks to the development of HT.

Epidemiological studies demonstrate an association between serum UA and both prevalence and new onset of essential HT in adolescents [6]. Recently, UA showed a strong independent relationship with BP values across different BP categories, from normal BP up to pre-and finally to established HT in children at relatively high cardiovascular risk [7].

Animal models support a two-phase mechanism for the development of hyperuricemic HT. Initially, UA induces vasoconstriction by activation of the reninangiotensin system and reduction of nitric oxide. Over

\footnotetext{
* Correspondence: francesca.viazzi@unige.it

'University of Genoa, Department of Internal Medicine, IRCCS, AUO San Martino-IST, Genova, Italy

Full list of author information is available at the end of the article
}

time, UA uptake into vascular smooth muscle cells (VSMC) causes cellular proliferation and arteriolosclerosis that impair pressure natriuresis, causing sodiumsensitive HT [8]. Increased UA causes endothelial dysfunction by inflicting oxidative stress once inside cells. UA internalization is mediated by URAT-1, and stimulates production of growth factors and chemokines in human VSMC [9] and increases ROS activating NADPH-oxidase, leading to apoptosis in human tubular cells [10]. These actions may, at least in part, explain the association between increased serum UA levels and initial cardiovascular and renal damage described in adolescents with obesity or HT $[11,12]$.

Interestingly, in both animal and human studies, allopurinol attenuates the development of fructose-induced HT by lowering UA. Indeed, lowering UA with either allopurinol or probenecid reduces BP in adolescents with HT or pre-HT $[13,14]$. While larger studies are needed, fructose assumption and serum UA are emerging as potentially modifiable risk factors for the prevention and treatment of HT in children.

\section{Authors' details}

'University of Genoa, Department of Internal Medicine, IRCCS, AUO San Martino-IST, Genova, Italy. ${ }^{2}$ Department of Health Sciences, University of Milano-Bicocca and Nephrology Unit, San Gerardo Hospital, Monza, Italy. ${ }^{3}$ Ospedale Pediatrico IRCCS Bambino Gesù, Rome, Italy. ${ }^{4}$ Family Pediatrician, Milan, Italy.

\section{Published: 30 September 2015}

\section{References}

1. Choi JW, Ford ES, Gao X, Choi HK: Sugar-sweetened soft drinks, diet soft drinks, and serum uric acid level: the Third National Health and Nutrition Examination Survey. Arthritis Rheum 2008, 59(1):109-116.

2. Grimes CA, Riddell LJ, Campbell KJ, Nowson CA: Dietary salt intake, sugarsweetened beverage consumption, and obesity risk. Pediatrics 2013, 131(1):14-21. 
3. Singh AK, Amlal H, Haas PJ, Dringenberg U, Fussell S, Barone SL, et al: Fructose-induced hypertension: essential role of chloride and fructose absorbing transporters PAT1 and GLUT5. Kidney Int 2008, 74(4):438-447.

4. Stirpe F, Della Corte E, Bonetti E, Abbondanza A, Abbati A, De Stefano F: Fructose-induced hyperuricaemia. Lancet 1970, 2(7686):1310-1311.

5. Nguyen S, Choi HK, Lustig RH, Hsu CY: Sugar-sweetened beverages, serum uric acid, and blood pressure in adolescents. J Pediatr 2009, 154(6):807-813.

6. Feig DI: Uric acid and hypertension. Semin Nephrol 2011, 31(5):441-446.

7. Viazzi F, Antolini L, Giussani M, Brambilla P, Galbiati S, Mastriani S, et al: Serum uric acid and blood pressure in children at cardiovascular risk. Pediatrics 2013, 132(1):e93-e99.

8. Feig DI, Madero M, Jalal DI, Sanchez-Lozada LG, Johnson RJ: Uric acid and the origins of hypertension. J Pediatr 2013, 162(5):896-902

9. Kang DH, Han L, Ouyang X, Kahn AM, Kanellis J, Li P, et al: Uric acid causes vascular smooth muscle cell proliferation by entering cells via a functional urate transporter. Am J Nephrol 2005, 25(5):425-433.

10. Verzola D, Ratto E, Villaggio B, Parodi EL, Pontremoli R, Garibotto G, et al: Uric acid promotes apoptosis in human proximal tubule cells by oxidative stress and the activation of NADPH oxidase NOX 4. PLOS One 2014, 9(12):e115210.

11. Pacifico L, Cantisani V, Anania C, Bonaiuto E, Martino F, Pascone R, et al: Serum uric acid and its association with metabolic syndrome and carotid atherosclerosis in obese children. Eur J Endocrinol 2009, 160(1):45-52.

12. Tomczak J, Wasilewska A, Milewski R: Urine NGAL and KIM-1 in children and adolescents with hyperuricemia. Pediatr Nephrol 2013, 28(9):1863-1869.

13. Feig DI, Soletsky B, Johnson RJ: Effect of allopurinol on blood pressure of adolescents with newly diagnosed essential hypertension: a randomized trial. JAMA 2008, 300(8):924-932.

14. Soletsky B, Feig DI: Uric acid reduction rectifies prehypertension in obese adolescents. Hypertension 2012, 60(5):1148-1156.

doi:10.1186/1824-7288-41-S2-A76

Cite this article as: Viazzi et al:: Sugar, fructose, uric acid and hypertension in children and adolescents. Italian Journal of Pediatrics 2015 41(Suppl 2):A76.

\section{Submit your next manuscript to BioMed Central and take full advantage of:}

- Convenient online submission

- Thorough peer review

- No space constraints or color figure charges

- Immediate publication on acceptance

- Inclusion in PubMed, CAS, Scopus and Google Scholar

- Research which is freely available for redistribution

Submit your manuscript at www.biomedcentral.com/submit 